Labruna, M.B.; Beringuier, P. Valorização e reconhecimento de práticas ecoturísticas como vetores de apropriação das paisagens no Parque Nacional da Serra do Cipó (MG). Anais do VIII Congresso Nacional de Ecoturismo e do IV Encontro Interdisciplinar de Ecoturismo em Unidades de Conservação. Revista Brasileira de Ecoturismo, São Paulo, v.4, n.4, 2011, p. 501.

\title{
VALORIZAÇÃO E RECONHECIMENTO DE PRÁTICAS ECOTURÍSTICAS COMO VETORES DE APROPRIAÇÃO DAS PAISAGENS NO PARQUE NACIONAL DA SERRA DO CIPÓ (MG)
}

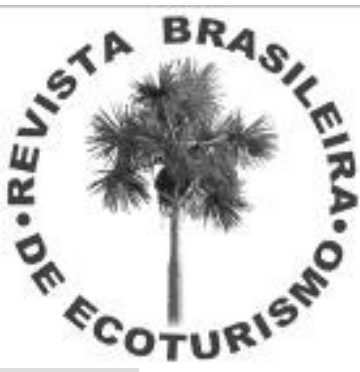

\author{
Marcio Bahia Labruna*, Philippe Beringuier** \\ ${ }^{*}$ FFLCH- Universidade de São Paulo, ** Université Toulouse Le Mirail \\ E-mails: marciobahia@hotmail.com, beringuier@wanadoo.fr
}

O desenvolvimento de atividades voltadas para o Ecoturismo ou Turismo Cultural (UNAT, 2002) favorece a abertura dos espaços de natureza (Grenier, 2000, 2002) onde a paisagem tem uma função de mediadora entre as novas formas de valorização e os territórios. Isto faz com que as paisagens apropriadas e valorizadas pelo ecoturismo se insiram na nova economia cultural do espaço, no qual o debate contemporâneo não cansa de testemunhar (Crang, 1997; Cosgrove, 1998 ; Terkenli, 2002, 2006). O presente artigo pretende colocar em evidência os processos de apropriação das paisagens, de uma parte, institucionalizadas através das Unidades de Conservação, e de outra parte, como conseqüência de sua ressignificação a partir das dinâmicas de valorização interna e periférica do ecoturismo, na qual estes territórios são objeto. Nós escolhemos como estudo de caso o Parque Nacional da Serra do Cipó, localizado a sudeste do Estado de Minas Gerais, na porção meridional da Reserva da Biosfera "Serra do Espinhaço". Partimos de uma abordagem voltada para a Geografia das Representações para compreender e explicar as representações dos grupos de atores institucionais (Parque Nacional Serra do Cipó, Reserva da Biosfera Serra do Espinhaço, Governo do Estado de Minas Gerais, Projeto Estrada Real e Operadores de Ecoturismo) e suas formas de planejamento e gestão do ecoturismo que dinamizam as paisagens a partir de novos valores inseridos neste. A Serra do Cipó faz parte de uma estratégia de gestão para conservação e preservação de paisagens ditas "fundamentais ", de grande valor estético, biológico e cultural. Seu território, marcado por uma descontinuidade nos níveis de proteção, é orientado para um objetivo comum de valorização das características naturais e culturais e como recurso patrimonial de importância local/internacional. Esta valorização se realiza a partir de diferentes níveis de exposição para e pelo ecoturismo, fator de produção de novos territórios. De que maneira o atual planejamento da atividade ecoturística não se encontra em vias de construir paisagens « espetáculos » a partir das atuais mutações nas formas, valores e usos na paisagem ? Nós assistimos, portanto, a uma construção social de novas identidades a partir de uma revalorização da natureza e cultura para fins de ecoturismo. Entramos na nova economia cultural do espaço com a emergência da renegociação cultural e da reinterpretação de novos modelos de paisagem nas Unidades de Conservação (PARNA, APA) e de suas dinâmicas socioculturais. A fronteira de proteção da noção do "wilderness " se reestabelece com a perspectiva do ecoturismo como o processo de desconstrução espaçotemporal, que redefine e reforça os particularismos locais (Tropeirismo, Estrada Real). Novas tipologias de paisagem a visitar são estabelecidas e as comunidades locais são motivadas a se ajustarem a esses novos modelos e modos de difusão dos fluxos socioeconômicos e à replicação de certas paisagens para apreciação estética exterior. Redefinem-se as práticas e usos nas paisagens da Serra do Cipó a partir do interesse regional/nacional/internacional produzido pelas representações sociais dominantes (ICMBio, Governo do Estado de Minas Gerais, Projeto Estrada Real e Operadores de Ecoturismo) que encontram-se em vias de construir novas sensibilidades às paisagens grandiosas e emblemáticas.

Palavras-Chave : Unidades de Conservação; Valorização Ecoturística; Planejamento Territorial. 